\title{
Disputed access to the gold sites in Luhwindja, eastern Democratic Republic of Congo*
}

\author{
Sara Geenen and Klara Claessens \\ Institute of Development Policy and Management (IOB), University of \\ Antwerp, Prinsstraat 13, 2000 Antwerp, Belgium \\ Email: sara.geenen@ua.ac.be
}

\section{A B S T R A C T}

In a context of increased competition over natural resources, large-scale investors are showing renewed interest in eastern Congo's mineral resources. At the local level this is resulting in fierce disputes over access to land and to mining sites. This article offers an empirical study of access in Luhwindja, where a multinational mining company has recently begun to exploit gold. We first sketch the context, examining the overlapping legal fields and analysing how various actors gain and control access to the gold mines. Next we study how the arrival of Banro Corporation in Luhwindja has altered power relations at the local level. Looking more specifically at the displacement of artisanal miners and the resettlement of local communities, we demonstrate how the company, local elites and the local population have engaged in a complex struggle for access.

\section{N T R O D U C T I O N}

All over the world competition over land and natural resources is mounting. One of the areas in which this is apparent is the struggle over mineral exploitation rights. This struggle has intensified since the liberalisation and privatisation of national mining sectors. In the course

\footnotetext{
* We are grateful to our colleagues from the Université Catholique de Bukavu: Gabriel Kamundala, Francine Iragi, Innocent Utshudi and Janvier Kilosho and to VLIR (Vlaamse Interuniversitaire Raad) and CEGEMI for financing. We also thank Serge Lammens, Pierre Merlet, Filip Reyntjens and two anonymous referees for their helpful comments. A previous version of this article has been presented by the first author at the conference of the Commission on Legal Pluralism, Cape Town, September 2011.
} 
of the 1990s, over 9o countries have rewritten their mining and investment codes, under considerable pressure from the World Bank (Bebbington et al. 2008: 889; Campbell 2009). These reforms were particularly aimed at increasing investments in the industrial and large-scale mining sectors. They have to a large extent neglected issues of socio-economic and community development and environmental protection. Whereas in many countries the reforms did succeed in attracting foreign capital, increased investments have also been accompanied by conflicts and concerns about the possible co-existence of industrial companies, artisanal miners and local communities. This co-existence may be threatened by opposite views on land use, environmental pollution and degradation of community's resources, human rights abuse and the loss of livelihoods (Hilson 2002; Ballard \& Banks 2003: 289).

In order to legitimise their respective claims to the land, industrial companies often insist on the fact that they have legally acquired permits and concessions, and they base themselves on state law. Local communities and artisanal miners, on the other hand, assert that they have the traditional right to work the land (Hilson 2002; Andrew 2003; Bush 2009). Both thereby adhere to different sources of law and authority. In this bargaining fight, large-scale actors seem to be advantaged because of their superior financial resources. They are also favoured by the official legal framework in many countries (Hilson \& Yakovleva 2007: 99; Andrew 2003: 119). State law renders many artisanal and small-scale activities illegal and weakens the rights of local communities neighbouring the mining sites, thus offering a considerable space for conflict, dislocation and disempowerment.

Yet in practice we see that large-scale mining companies, local communities and artisanal miners often meet in complex arenas where multiple legal orders co-exist and where the state law is not the only, nor the first, source of law and authority. This is certainly true in the Democratic Republic of Congo (DRC). The country is still recovering if at all-from many years of violent conflict that especially affected the eastern part. In these conflicts mineral resources have played a destructive role. And while mineral exploitation is still being associated with violence and conflict, the mining sector is also supposed to contribute to the fragile post-conflict reconstruction. But the Congolese state and its institutions are extremely weak. The state is not able to effectively deliver public services, provide protection for its population, control its territory, generate taxes or enforce its legislation. All this adds to the complexity of the institutional landscape. 
In order to unravel some of these complexities, this article offers an empirical study of access to the gold mines in Luhwindja, a chiefdom in Mwenga territory, in the province of South-Kivu, eastern DRC. In the second section we provide a context, describing how access to land and mineral resources in eastern DRC has shifted over time. The third section summarises our theoretical approach and introduces the concepts of 'legal pluralism', 'property' and 'access'. In the fourth section we disentangle the access mechanisms used by the artisanal gold miners and a multinational gold mining company, Banro Corporation. Before concluding, the fifth section analyses how Banro, local elites, and the population have engaged in a complex power struggle around access control.

We base our analysis on fieldwork in Luhwindja and Bukavu (January and October/November 201 1, May/June and September/October 2012) and South-Kivu in general (2008-2012). In Luhwindja we did more than 70 in-depth interviews with (former) artisanal miners, Banro's employees, community leaders, traditional and state authorities, civil society members, four focus group interviews with artisanal miners and three with the local community. We also collected numerous documents (letters, court decisions, statements, pictures) and participated in a number of meetings. In order to guarantee their anonymity interviewees are only identified by their position.

SHIFTING ACCESS IN EASTERN DRC

This section describes how access to land and mineral resources in eastern DRC has shifted over time. Over the last decades land tenure arrangements have been put under serious pressure due to population growth, opportunistic behaviour of the local elites and an increasing number of land claims for other than agricultural purposes, such as the exploitation of forestry and mining resources (Utshudi Ona \& Ansoms 2011 ).

Customary tenure arrangements are based on collective ownership, kinship loyalty and mutual interdependence. In the area we are studying, this system has been described as 'an institution that legitimises the whole social organisation by absorbing all persons within a given area into a network of dependent relations' (Van Acker 2005: 81). The customary contract, of which the 'kalinzi' is the most common form, implies tight hierarchical relationships with the top the allocator of the land, the king or 'mwami'. The latter may grant non-alienable inheritable user rights to a person who gives him the 'kalinzi', mostly in 
the form of cattle, and thus becomes the king's subject (Vlassenroot \& Huggins 2005).

The colonial administration introduced a dual system and made a division between 'state land' governed by state law and 'indigenous land' governed by customary law. This duality persisted until the introduction of the General Property Law in 1973 that proclaimed all land state property. The state may now grant temporary or perpetual user and withdrawal rights to moral and physical persons respectively, in the form of 'concessions'. With this law customary authorities lost their de jure control over the allocation of the land. Article 389 , however, stipulates that land occupied by local communities may still be held under customary arrangements. The specificities for this were to be formulated in a presidential decree. But that decree has not been issued yet to date (Utshudi Ona \& Ansoms 2011).

As a consequence land arrangements are characterised by high levels of ambiguity regarding the legal status, the rights of the users and the authorities responsible for governing it (Mugangu Matabaro 2008). Due to the weak implementation capacity of the Congolese state, the de facto duality between state land and customary land has persisted. During the 1998-2003 conflict access patterns changed through several mechanisms, including forced displacement and the hardening of social and ethnic boundaries (Vlassenroot \& Huggins 2005). In addition, the power of the traditional authorities was challenged by the development of militarised networks. A growing group of landless and marginalised young men provided these new military groups with a fertile ground for recruitment.

In brief, the traditional patron-client relationships were undermined and replaced by new forms of patrimonial relations based on economic gain and wealth accumulation. Local customary chiefs tried to maintain their position by becoming the 'gatekeepers for shifting the asset from customary control to the modern legal system'; 'they occupied the perfect position to manipulate the duality of the new land legislation to their own advantage' (Vlassenroot \& Huggins 2005: 135). Along the same line, Mugangu Matabaro (2008) points to the discrepancies in norms used by the customary authorities on the one hand and the farmer population on the other. Customary authorities hold on to the customary contracts in order to prevent farmers from obtaining official titles (concessions), and thus retain control over their 'subjects'. Farmers for their part interpret a customary contract more and more as a commercial transaction, granting them a perpetual concession title (Mugangu Matabaro 2008). 
The subsoil in eastern DRC is rich in minerals, especially cassiterite, coltan and gold, whereas copper and cobalt are found in Katanga and diamonds in Kasai (Geenen 2011a). During colonisation, vast areas of land were given in concession to mining companies such as 'Union minière du Haut-Katanga' (UMHK) in Katanga, 'Minière de Bakwanga' (Miba) in Kasai, 'Office des mines d'or de Kilo-Moto' (Okimo) in Ituri and 'Minière des Grands Lacs' (MGL) in Kivu. These companies governed their concessions as private domains, restricting access for outsiders and providing public services for workers and their families (Hönke 2010). In the late 196os, in an attempt to become economically more independent from the former colonisers, Mobutu nationalised the most important companies (UMHK for example became Gécamines in 1967). The state, now being the owner of the land as well as the subsoil, could grant concessions to companies or individuals for the exploitation of these minerals. But due to bad management, and combined with a more general economic crisis, the nationalisation and 'Zairianisation' measures (1973) had a disastrous effect on Congo's mineral production (Geenen 2011a).

During the same period many Congolese started to exploit minerals in abandoned shafts or riverbeds in an artisanal way. Although these activities were strictly speaking illegal, they were an answer to the generalised and growing economic, financial and political crises. Relying on this artisanal exploitation, an illegal trade network developed, efficiently linking the local level to cross-border trading hubs in Rwanda, Uganda and Burundi. In 1982 Mobutu liberalised the gold and diamond sector and thus opened up artisanal exploitation and trade for all Congolese, but this measure was only valid outside the private concessions. This restriction was not put in practice, though, as people started to dig almost everywhere.

In the course of the 1990 industrial production fell close to zero, and the Zairian government was bound to privatise mining companies (joint ventures with Gécamines and a range of contracts that were concluded in 1996; Kennes 2005: 162). At the same time, artisanal production and illegal trade exploded and intensified, certainly during the 1996-97 and 1998-2003 wars. During the second war, existing politico-commercial networks in the east linked up with armed groups and with external financiers, and control over the mining sites and trade routes became an important incentive for fighting. Neighbouring Uganda and Rwanda became directly involved in the plunder of Congo's resources (see various United Nations [UN] reports and Marysse 2005). At the local level, this war situation created 'new local complexes of power, profit 
and protection', disrupting traditional social and economic structures and leading to social transformation (Vlassenroot 2004: 40).

In the early 2000s, the Kabila government embarked on the path of legal reforms. As in many other countries, the new Mining Law ${ }^{1}$ (2002) and Mining Regulations ${ }^{2}$ (2003) were established under the guidance of the World Bank and the International Monetary Fund (IMF), whose influence is obvious in the primacy of private sector development and the priority of industrial, large-scale projects (Mazalto 2009). Every physical and moral person can apply for a research permit which is valid for a period of four years, possibly being renewed up to eight years. If the holder of a research permit finds promising deposits, he may apply for an industrial exploitation permit, valid for a period of $3^{0}$ years and subjected to a quite liberal tax regime. Deposits that are judged not suited for industrial mining may be covered by a small-scale mining permit.

The law also explicitly recognises artisanal mining. It stipulates that the Ministry of Mines may demarcate 'artisanal exploitation zones' (AEZ) in areas where 'the technological and economic factors are not suited for the site to be industrially exploited' ${ }^{3}$ The law provides for a possibility to close down the AEZ if 'the factors justifying its creation ceased to exist', or if a 'new deposit necessitating large-scale exploitation has been discovered'. ${ }^{4}$ Thus, in practice, large-scale actors can always have the upper hand. Miners who want to work in an AEZ need to acquire a special permit with one-year validity and have to comply with the regulations on security, hygiene, water use and environmental protection specified in the Mining Regulations. ${ }^{5}$

Many of these legal provisions have never been put into practice though. As a result, artisanal exploitation and trade continue to flourish through actors and networks operating outside the state's regulatory framework. ${ }^{6}$ At the same time, large concessions in the eastern provinces have been attributed to industrial mining companies (as a result of contracts concluded in the 1990s), who are now starting to explore and produce. In this institutional environment the gap between law and practice is vast, and the distinction between 'legal' and 'illegal' blurry. Therefore we need a different conceptual framework to make sense of access to land and to mineral resources in eastern DRC.

LEGAL PLURALISM, PROPERTY AND ACCESS

Legal pluralism refers to the co-existence of different normative systems and of different norm-producing authorities such as the state, customary 
and religious authorities, economic authorities and local communities. '[It] draws attention to the possibility that within the same social order, or social or geographical space, more than one body of law, pertaining to more or less the same set of activities, may co-exist' (Von BendaBeckmann \& Von Benda-Beckmann 20o6: 14). On certain levels interacting normative systems may clash, thus causing conflict and transformation. For example, multinational companies may adhere to specific norms relating to property rights. These may be inconsistent with prevailing customary norms, which often characterise property in more collective terms (Tamanaha 2008).

Legal pluralists define property simply as an enforceable claim to the use or benefit of something (Sikor \& Lund 2009: 4). This encompasses any claim which is socially sanctioned, be it by convention, customary law or state law (Meinzen-Dick \& Pradhan 2002). But not all claims can be considered as 'socially sanctioned', and the fact that people are able to benefit from something does not necessarily imply that they have property rights. Therefore 'access' has been introduced as a broader concept, encompassing all manners in which people benefit from things, and defined by Ribot \& Peluso (2003: 153) as 'the ability to benefit from things' (our emphasis).

Unlike Schlager \& Ostrom (1992), who define access as an operational property right ('the right to enter a defined physical property'), Ribot \& Peluso (2003: 153) clearly distinguish property rights from access by focusing on ability, which 'brings attention to a wider range of social relationships that can constrain or enable people to benefit from resources'. In this sense, the concept of access is empirically more useful and 'facilitates grounded analyses of who actually benefits from things and through what processes they are able to do so' (2003: 154). Ribot \& Peluso explicitly refer to legal pluralist property theory, which acknowledges that external factors (politicaleconomic, cultural, social) determine who can use law, custom and convention, and in what ways. This idea is most obvious in the notion of 'forum-shopping', the agency or 'ability of some actors to select the arena of law, custom, or convention that will favour their objectives' (2003: 157; Von Benda-Beckmann 1981; Griffiths 1986).

Ribot \& Peluso take their analysis further by looking at access relations, which are fluid and depend upon an individual's or group's position and power within different social relationships (2003: $15^{8}$ ). In other words, changing political-economic circumstances 'change the terms of access and may therefore change the specific individuals or groups most able to benefit from a set of resources' (2003: 158). This will 
become clear when we describe, for example, how actors have been able to use the war context in eastern DRC to gain access. Access, in other words, may also be obtained or enforced through violence and coercion.

In an attempt to clarify the political-economic dimension of these relations, Ribot and Peluso distinguish access 'control' and access 'maintenance', the former being the ability to mediate other people's access (by people in power positions), while the latter encompasses attempts to keep a particular resource access open (by less powerful actors who have to gain access through someone else; 2003: ${ }_{15}^{8)}$. The processes through which people do this, or the so-called 'mechanisms of access', can be of various kinds: rights-based (sanctioned by law, custom, and convention or unsanctioned, by theft, coercion or violence), structural (access to technology, capital, markets, labour, knowledge, authority and information) or relational (access via the negotiation of social relations of friendship, trust, reciprocity, patronage, dependence and obligation). In the next section we unravel the access mechanisms used by the company Banro and by the artisanal gold miners of Luhwindja, respectively.

ACCESS MECHANISM S

\section{How Banro corporation gained access to the gold mines ${ }^{7}$}

Gold and cassiterite (tin ore) have been mined in the Kivus since the 1920 , first by the Belgian company MGL, later by its successor Sominki ('Société Industrielle et Minière du Kivu'). In the early 199os Sominki's production had drastically declined and they were looking for a buyer. The Canadian junior company Banro Corporation, aiming at exploration and speculation on promising deposits, showed an interest. But they only aspired to gold concessions, as was demonstrated by a feasibility study presented in January 1996 after a technical mission had been sent to the four main gold sites (Twangiza, Lugushwa, Kamituga and Namoya). In order to understand some of its actions, it is important to remember that Banro is a junior company that is in the first place accountable to its investors and stockholders and needs to play the game according to the norms set by international stock markets (Kennes 2005: 157-159). This means among others that they have to be able to quickly capitalise on changes in commodity markets and be willing to take enormous risks.

In the first instance Banro concluded an agreement with the British Cluff Mining, which brought in most of the financial capital, but 
after months of pressures and power play Banro managed to get rid of Cluff and in February 1997 all Sominki's concessions were transferred to Banro. ${ }^{8}$ Sominki was liquidated on 29 March 1997. In the meantime Banro was negotiating both with the moribund Mobutu regime and with Laurent Kabila. Kabila promised Banro they would respect their titles to the four gold concessions. The negotiations with Mobutu's government resulted in the creation of a new company, Sakima ('Société Aurifère du Kivu-Maniema'), with $93 \%$ of the shares belonging to Banro and $7 \%$ to the Zairian state on 6 May 1997, just a few days before the seizure of Kinshasa by AFDL ('Alliance des Forces Démocratiques pour la Libération du Congo') forces of Laurent Kabila. In order to dispose of the tin concessions, Banro handed them over to a subsidiary they had created: Ressources Minières Africaines (RMA; see note 12).

After the coming to power of Laurent Kabila, Sakima effectively started large-scale exploration works in Twangiza. But the company did not honour any of its obligations towards the former Sominki personnel or to the supply companies. On $3^{1}$ July 1998 Laurent Kabila deprived Banro of its mining titles because of 'irregularities in the liquidation of Sominki and the creation of Sakima'. The president created a new stateowned company: Somico ('Société Minière du Congo'). ${ }^{9}$ This may be interpreted as a strategy to control and centralise revenues in the hands of the new regime. But there was also a more fundamental and 'nationalist' dimension to it, as the Kabila regime wanted to reform the mining sector and make it more independent from major AngloAmerican companies (Kennes 2005: 163). It is also symptomatic that Kabila appointed the mwami of Luhwindja, Philemon Naluhwindja, as director of Somico. Naluhwindja had always contested the concession rights of Sominki on the land that he governed in accordance with customary law, and thus represented the 'traditional' rights holder, as opposed to the external investor. Naluhwindja had also organised and substantially benefited from artisanal exploitation (see below). He was murdered on 20 December 2000 in France. ${ }^{10}$

Two days after Somico's creation, the RCD ('Rassemblement Congolais pour la Démocratie') rebellion had broken out, and large parts of South-Kivu were seized. During the 1998-2003 war, Banro was close to the RCD, ${ }^{11}$ whereas Somico allegedly supported Mayi-Mayi and later FDLR ('Forces Démocratiques pour la Libération du Rwanda') groups and was backed by the Kabila government. Thus the access to the gold mines was at stake in a highly politicised battle, and the gold mines were alternatively occupied by one of these military groups. In this case, enforcing access through violence and through 'illegal access 
mechanisms' (Ribot \& Peluso 2003: 162) seemed to be a more successful strategy than using legal mechanisms.

But meanwhile Banro pursued other legal access mechanisms. They filed a lawsuit before a tribunal operating under the auspices of the International Centre for the Settlement of Investment Disputes (ICSID), which proclaimed itself incompetent in 2000. In January 2001 they filed a new lawsuit against the Congolese state, disputing the loss of Sominki's concessions and demanding a compensation of US\$1 billion before the United States Federal Court, invoking the 'Foreign Sovereign Immunities Act'. However, on 16 January President Laurent Kabila was murdered and succeeded by his son Joseph. Banro invited the Congolese government to negotiate a 'gentlemen's agreement', which was eventually signed on 18 April 2002. The agreement restored all titles and rights to Sakima/Banro. It states that Sakima keeps the rights to 35 tin concessions and becomes a fully-owned state company. It further stipulates that Banro may exploit 12 gold concessions in Twangiza, Kamituga, Lugushwa and Namoya. The gentlemen's agreement extended the duration of the contract from 25 to 30 years and preserved the extensive tax holidays. ${ }^{12}$ Yet a 2010 amendment to the agreement, a result of a renegotiation demanded by a government commission that evaluated the mining contracts (Ministère des mines RDC 2007), to a certain extent limits the tax holidays, as Banro is required to pay an annual $4 \%$ on its net revenues and $1 \%$ royalties to the Congolese state, starting from the production phase. ${ }^{13}$ Banro first started research and exploration works in Twangiza, a mine situated in the chiefdom of Luhwindja, at about 40 kilometres southwest of Bukavu. The research phase lasted about six years. In November 2011 Banro entered the 'production phase' in Luhwindja.

The arrival of Banro introduced a new layer in the legal pluralist landscape. Just like the industrial companies that operated before the war, Banro is navigating between the international, national and local legal fields. But the context has changed. As we stated at the very beginning of this article, competition over mineral resources is growing on a global level. This is among others a result of geopolitical power plays for strategic access to mineral deposits. Second, the price of gold has boomed since the financial crisis of 2008 , which has placed Banro in a very favourable position. Third, the negative image of mineral exploitation ('conflict minerals' and bad human rights outcomes) has led to strict obligations for due diligence and corporate social responsibility (CSR). Companies like Banro are thus required to comply with guidelines (OECD, World Bank) for involuntary resettlement and 
CSR. National legislations have also changed and generally favour industrial and large-scale mining, as we said in the introduction. This is the case in the DRC as well. Finally, the subsequent conflicts in eastern DRC had a profound impact on local societal dynamics and power relations, and reshaped access to land and to the mines, as we explained.

The Banro case clearly shows that property and access do not necessarily overlap, as concession rights may be granted and taken away by subsequent authorities. Moreover, access may be enforced through violent mechanisms. While this section has mainly highlighted rightsbased mechanisms, it needs to be said that Banro also makes ample use of structural and relational access mechanisms. As we have pointed out in the introduction, in the bargaining fight over mineral rights multinational mining companies are usually better equipped than artisanal miners because of their access to technology, capital, markets and information. With their advanced technology, companies are able to more efficiently explore and extract minerals from certain deposits. Access to capital typically comes in the form of credit, which is only limitedly available to artisanal miners. There is also a considerable difference in market access as artisanal miners are only at the bottom of a long value chain with many intermediaries. Access to information or knowledge, finally, also determines to what extent someone may benefit. Finally, as we will show later, the company established cordial relations with local and national political and military authorities, both state and non-state. In the next section we will nuance some of these statements by showing how artisanal miners use similar mechanisms, although they take a different form.

\section{How artisanal miners gain access to the gold mines}

In 1975 MGL abandoned its concessions in Luhwindja, which had become unprofitable. Shortly afterwards the shafts and alluvial sites were occupied by artisanal miners. The alluvial sites were mainly situated in the Mwana and Lulimbohwe rivers and are sometimes referred to as 'Twangiza', which has become a kind of pars pro toto for the sites where Banro will start production. The water in these rivers was diverted into little muddy currents so as to be able to pan for gold. Underground shaft mining was concentrated in Mbwega, Lukunguri and Kaduma. In Mbwega, there were reportedly more than 600 shafts. According to Observatoire Gouvernance et Paix (OGP; 2008: 29) more than 5, ooo households were dependent upon the gold exploitation in Mbwega. 
With respect to the total number of miners in Luhwindja, estimates go from 6,ooo to 12 ,ooo. These were mostly autochthones (about $70 \%)$, but there were also miners from other areas, primarily from the neighbouring chiefdoms of Burhinyi, Ngweshe and Kaziba (OGP 2008: 27).

Gaining access to a mining site depends on both structural and relational and rights-based mechanisms. In underground mining the so-called 'PDG' ('Président Directeur Général') or shaft manager takes the initiative to start mining. He provides the necessary tools (shovels, chisels, torches and water pumps), engages a team of workers and caters for their food-and possibly other needs-until the shaft starts 'producing' (i.e. when the team reaches the gold vein). Between five and $15^{\circ}$ miners may work in one shaft depending on the availability of manpower, the size of the shaft, the phase they are in and the expected production. The work is done manually and miners make use of shovels, chisels and other small tools. A few shaft managers also invested in machines like water pumps and compressors. All in all, an underground shaft-mining project requires considerable investment (about US $\$ 1,5^{\circ}$ oO a month on average). In some cases teams have to work a year or more before they reach a gold vein. As a consequence, investments in shafts may run to tens of thousands and even more than US\$100,ooo before the shaft eventually produces.

For artisanal miners, gaining access thus essentially depends on access to capital and technology. Since they have no access to formal credit, they constantly make credit arrangements with local traders. As we have argued elsewhere (Geenen, 2011b, 2012) these relations are well regulated and provide for delicate power relations. Similarly, shaft managers invest in social relations with miners and vice versa. Shaft managers need a flexible labour force with specialised workers such as 'boiseurs' (who shore up the shaft with wooden trunks), 'foreurs' (who extract the auriferous rocks), 'conducteurs' (who orient and oversee the work) and 'bouts de feu' (who use explosives to open up new shafts). Miners obviously need to maintain their access to labour opportunities. Their recruitment is generally based on friendships and (extended) family relations. Finally, artisanal miners also maintain their access through access to knowledge (for example acquired knowledge about the situation of gold veins) and information (for example about the world market price, on which they are now informed via mobile phones).

Artisanal miners rely on rights-based mechanisms as well. They first of all legitimise their claims by referring to their 'traditional' rights to the 
land which their ancestors lived and worked on. As one interviewee told us in Kamituga (the other former MGL site): 'We only take what is ours; it's the land of the Congolese' (miner Kamituga 2008 int.). Another miner said: 'We are born here, our parents worked in the company. Being their children, we have the right to work in these mines' (miner Kamituga 2008 int.). This argument is made by artisanal miners all over the world, as for example in the case of Ghana (Aubynn 20og: 66). Another argument to legitimise the miner's claims is to be found in the relative absence of the state performing its core functions. This is tangible in a statement made by a former MGL employee, who is now in his $70 \mathrm{s:}$

Mobutu has chased away MGL and instructed all of us to use our own force, he chased the white people. [...] And when they had left, we stayed here. When the president told us to fend for ourselves, we started this work of digging gold. (MGL employee 2011 int.)

He thus explicitly refers to Mobutu's liberalisation policy and implies that the state has retreated consciously, while leaving the land to the local population to mine on. Currently the state is still unable to deliver services such as education and health, security and socio-economic development. It is widely accepted that, in such a situation, 'communities are likely to be more inclined to have less regard for the authority and claims of the state' (Ballard \& Banks 2003: 296).

As we have demonstrated the mwami traditionally was-and in practice still is in many cases - the allocator and safeguard of the land. Therefore he also had an important role to play in artisanal mining. Once a miner had identified a site, secured funding and labour, he first had to go and see the chief. A former miner told us: 'I went to the chief and asked to give me the plot, since he was distributing all the sites' (leader artisanal miners 2011 int.). Another one recounts:

I was a veterinary, working in the public administration. So you know, the difficulties we have with the government, no salaries, or very little salaries [...] The beloved mwami has given me a pit in Mbwega in 1990. (former shaft manager a 2011 int.)

As did the previous one, this quote also highlights the ineptitude of the state to 'provide for' its citizens, as well as the role of the customary chiefs in this context. But in exchange for access, miners need to pay regular contributions to the chief. The latter sends his representatives or 'baganda' to collect the monthly tax or 'citore', usually equal to one gram of gold. He also levies additional taxes on production, according to some sources amounting to $10 \%$ of the production (sometimes 
expressed in quantities of gold, sometimes in centimetres of excavated rocks; former shaft manager a 2011 int.). Although this does not conform to state law, it gives the shaft managers tenure security because of the legitimacy of a customary title, which is still very prominent in the land tenure system, as we have pointed out. One former shaft manager expressed it as follows: 'I have acquired this title in a customary way, so it may not be a "very official" title, but it is my pit' (former shaft manager b 2011 int.).

Nevertheless, in order to secure their access, miners also engage in forum-shopping. They approach and are approached by multiple authorities: state representatives, people from the mining administration or 'Saesscam' (the technical service of the ministry of mines to assist artisanal and small-scale miners), military leaders, local leaders, associations and cooperatives, to whom they pay a whole range of official and non-official taxes. Officially artisanal operators should buy a permit ('carte d'exploitant artisanal'), for which no amount is specified in the Mining Regulations. In practice, most do not have such a card, but some do, and they pay amounts between US\$25 and 125 , depending on the person and his negotiation skills. Especially when a shaft is in production, they are required to pay many additional contributions to one of the above-mentioned authorities.

Obviously not all these transactions are voluntary, so there certainly is an element of extortion, resulting from unequal power relations. On the other hand, miners deliberately use these payments as an access mechanism. When they pay their claims may be registered or written down, which increases their feeling of tenure security. Besides, they negotiate over the amounts all the time, and are thus trying to manoeuvre themselves in a more favourable position vis-à-vis these authorities. The endless negotiations and attempts to get the most favourable outcome in these unfavourable circumstances may be captured under the mechanism of forum-shopping.

These observations also demonstrate that not only miners are involved in forum-shopping. In the same way the state agents, customary chiefs and local leaders use their position vis-à-vis the miners to gain access, to benefit, and to establish or reinforce their power position (von Benda-Beckmann 1981: 'shopping forums'). They are positioning themselves in a new and changing political and economic landscape. By using strategies adapted to the new institutional landscape they are trying to again control access. In the next section we will further illustrate this. 


\section{Contestations, resistance and negotiations}

As we have demonstrated, the arrival of Banro in South-Kivu was shadowed by conflicts of interest (with Somico) and full-scale war. In Luhwindja, this played out in a rivalry within the royal family. The death of mwami Naluhwindja caused a succession conflict as the eldest son had not yet attained the age of majority and resided in Europe. The 'bagingi', the elders, appointed the mwami's younger brother Justin as regent, and his widow Espérance Barahanyi as 'mwamikazi' or guarantor of the customs. Justin reasoned that, following the example of his brother, supporting Somico would give him the best chance to keep on controlling the access to the gold mines. Meanwhile, however, Joseph Kabila had deviated from his father's path and negotiated a gentlemen's agreement with Banro. In order to facilitate Banro's installation locally, Kabila contacted the mwamikazi, who became closely involved.

Concurrently, as Somico was never able to really invest, Justin was effectively controlling and deriving rents from artisanal exploitation, and had contracted FDLR soldiers as personal security guards. He had convinced part of the population that Somico was 'their' company and they should not let the 'foreigners' occupy their land. In July 2005 however the Congolese national army launched an operation to chase FDLR and install Banro, protected by special military forces, who took violent action against the population. Justin, who went to Kinshasa, was elected as a member of parliament in 2006, but shortly afterwards the Supreme Court invalidated his mandate. Part of the population, however, still sides with him, and he also gets support of Kantintima, a powerful politician (South-Kivu's governor under RCD rule and former minister of agriculture, now Member of Parliament). Banro was thus faced with a quite hostile environment, and in October 2005 they called the mwamikazi to quieten things down. By taking some development initiatives and rehabilitating public infrastructure, they sought legitimacy from the community'.

But the community itself was not involved in any discussions on local development programmes. Negotiations were held with the mwamikazi and the members of Codelu ('Comité de Développement de Luhwindja'), a membership organisation for people from Luhwindja living in Bukavu and consisting mainly of urban elites. Meanwhile, Banro intensified its prospection work and started drilling. They also began to work on the main road connecting Luhwindja to Bukavu, a rehabilitation project that was partly financed by the World Bank. But 
there were no provisions to compensate the local population for property loss. With respect to the construction of the road, for example, the argument was that this facility was to serve a 'public interest', and thus 'expropriated' land did not need to be compensated for (lawyer 2011 int.). All this resulted in heated protest demonstrations. A prominent opponent explains:

I was standing first in row to fight Banro. Why? Because our rights had been violated! To save our rights, we have done everything; we opposed ourselves, we barred the road. [...] We claimed our rights. They called in the police and the military. But we told them we were prepared to die. Because I have my field, and that's my life. (Community leader 2011 int.)

His words demonstrate that the rhetoric of rights is prominent in their discourse and acts of resistance. He refers in the first place to the population's loss of livelihoods, namely the work they do in the mines, and the crops they cultivate: 'If I exist today, that is thanks to my field there. There is no living without it' (community leader 2011 int.).

Banro understood that, in order to secure its own economic and security interests, a negotiated approach was needed. In 2009 they instituted a community forum that was supposed to represent the interests of the community in negotiations over resettlement and compensation. But who can legitimately claim to represent the community? This seems to be a matter of access control, since identifying so-called representatives is a profoundly political process and is influenced by and influences local power relations. Ballard \& Banks (2003: 302) observe that, in many cases, the 'representative committee' is in fact composed and steered by the companies themselves. In Luhwindja this certainly held true. The forum was assembled and financed by Banro, and the advocates of the company clearly outnumbered the others. The 'working group on compensation', for example, consisted of nine Banro representatives, four community representatives, the mwamikazi and the 'chef de poste' (local state representative), who is also known as a close collaborator of Banro.

\section{Displacement and reintegration of artisanal miners}

A first issue that was addressed in the community forum was the displacement and 'reintegration' of former artisanal miners. Since its arrival, Banro has closed some of the most important artisanal mining sites in Luhwindja. They first targeted Mbwega hill. In 2010 they closed the sites of Kaduma and Lukunguri. The miners in the riverbeds of Mwana River were tolerated. Yet they were heavily affected by Banro's 
upstream activities diverting the water from the artisanal miners downstream. In early 2010 Banro contracted Saesscam to identify and register the artisanal miners working within the Twangiza concession, with the aim of converting them to other activities. But the miners welcomed this census with a lot of suspicion and scepticism. Saesscam, as other state services, had always been considered as an extractive body, for which the sole aim was to levy taxes and which never did anything to assist or support the artisanal miners. Initially only 202 miners volunteered (former miner a 2011 int.). Saesscam had to organise several rounds of field visits to eventually identify 903 persons, while the real number was at least six times higher, as we indicated (leader artisanal miners 2011 int.). The latter then had to choose between being employed by one of Banro's subcontracting companies, or following a professional training and conversion programme.

This 'conversion programme' for artisanal miners has had mixed results. At the local level four non-governmental organisations (NGOs) were subcontracted to organise professional training in carpentry, bricklaying, car mechanics, sewing and so forth. Under-age children were sent to school or could also opt for professional training. Each NGO has trained between $5^{\circ}$ and 100 former miners. Some of these programmes were successful while others were affected by corruption and embezzlement of money. A few hundred former miners were hired to work for Banro through a system of subcontracting. Some of these subcontracting companies (for labour, but also for road works or specific construction works) are owned by customary chiefs (Cinamula by the mwamikazi of Luhwindja; Zuki by the mwami of neighbouring Burhinyi), others by urban elites or foreigners. According to our sources, day labourers earn US\$4 -6 a day. For the former miners this salary, albeit stable and predictable, is not satisfactory. Most of them affirm they earned much more in the shafts: 'They said the company would come to enrich us, but they are rather impoverishing us' (former miner b 2011 int.). A local chief complained:

They promised to give us work, but this is insufficient! Eight per cent of the people in my 'groupement' ${ }^{\text {'3 }}$ lost their job. What are they going to do now? [...] How can someone who earned 100 dollars per week or sometimes even per day accept to work for US\$4? (Chef de groupement 2011 int.)

As day labourers these former miners' income remains as unstable as before. Moreover, they are entirely dependent upon the company, whereas an artisanal miner is considered to be mainly dependent upon 'his own force'. The negative effects of Banro's employment policy 
became clear in mid-2011 when Banro, concluding the exploration phase and moving towards exploitation, dismissed a large number of former artisanal miners. In reaction, several hundreds of them reoccupied the sites, specifically Kaduma and Lukunguri, from March 2011 onwards. They enforced their access, in the eyes of the company and the state representative, by illegal means (chef de poste 2011 int.), whereas to their own judgement they were only exercising their rights which had been 'violated by the company' (miners focus group 2011 int.). They claim that, if Banro shuts down the mines and thus threatens their livelihood, they need to give them proper work:

They are fooling us. They say they will give you work and the next day they chase you off. If they were planning to stay, they would make us sign contracts. We have no prospect to work. So the only choice we had was to reoccupy this concession. They threatened us with policemen and dogs. We told them to do what they want, but we will not die because of hunger! [...] We would rather die by a bullet than die of hunger. (Miners focus group 2011 int.)

Acknowledging the fact that it is indeed difficult to provide alternative activities and that the company is not able to absorb this big labour force, Banro for the time being tolerated the miners in Kaduma and Lukunguri, although security guards were regularly patrolling at the site. The company is now also pursuing other paths such as credit facilities for local companies who intend to employ former artisanal miners, and negotiations with the Mining Registry to cede concessions outside Twangiza to artisanal miners (businessman 2012 int.).

\section{Resettlement and compensation of local population}

The community forum was also involved in the talks about a compensation and resettlement scheme. After a survey that was carried out by a consultancy firm in July 2008, Banro identified 463 households for resettlement from the 'core zone' where it planned to build the factory and start open pit mining. According to Banro's community relations manager, this would affect 2,00o to 2,500 persons out of the $5^{2,000}$ people living in Luhwindja chiefdom (public relations manager 2011 int.). The company also imposed a moratorium on the building of new constructions or the planting of new crops, which makes it difficult for people to carry out their agricultural activities at the risk of losing investments.

The resettlement site that was chosen is Cingira, an extremely remote place at 1,700 metres altitude with a cold climate. Explanations as 
to how and why Cingira was chosen differ. According to some this particular hill was previously known as the 'granary of Luhwindja' where people cultivated maize, beans and potatoes and pastured their cattle. Higher up, the risk of malaria is smaller, and 'negative' influences of Banro's presence such as alcoholism, prostitutes and AIDS would not bother the population. Besides, moving the population to another 'groupement' would mean a loss of status for the local chiefs and elites (community leader 2011 int.). According to others, the climate and soil in Cingira are extremely hostile, and Banro has forced the community to move there. Still others claim that the preference for Cingira was a sign of 'stubbornness of the people over there', or even a deliberate strategy to make the company give up and leave, because the population assumed Banro would never be able to build up a village in such a remote site. But Banro did build the village on a concession that was given to them by the mwamikazi. At the time of our visit in January 2011, 109 households had already been resettled. By late 2011, however, there was more and more talk about the worrying quality of the houses, and the fact that a number of households had already left Cingira because of the harsh living conditions.

As for compensation, the eventual agreement (February 2010) materialised in a list of compensation rates for crops and trees respectively (Banro 2010). But the problem is that crops planted after the SRK Consulting survey in 2008 are not counted because of the moratorium. Also, secondary building structures would be recompensed at a rate of $150 \%$ of their value. But the main structures (family houses) are not financially rewarded. They are replaced by a construction which adheres at least to the same standards as the current one, to be built in Cingira. A final problem is that Banro bases its compensation scheme on the Congolese land code, according to which only an official land title, not 'occupation' as considered by customary land rights, entitles people to be compensated for the loss of land (Banro 2010; lawyer 2011 int.). Unlike the crops and buildings on the land, the land itself is thus not compensated. In their negotiations with the community forum Banro emphasised that they cannot compensate the land as such since they have "no rights whatsoever on the surface' (Forum Communautaire Consultatif de Luhwindja 2010). They can only negotiate with the customary chief, who may place new plots of land at the population's disposal, and that is exactly what they agreed upon.

Nevertheless, compensation and resettlement are still causing many conflicts at the local level. By late 2011 at least 28 related cases had been 
brought to court (local NGO 2011 int.). An illustrative example is the case of a group of women (focus group 2011 int.) who protested against Banro by throwing themselves in front of the bulldozers that were sent to trace a road through the land they used to cultivate. These women had not been offered compensation since they held a customary title. In addition, their plants were, at the time of expropriation, not yet older than six months, so that they were also considered not entitled to compensation for the crops. The women were arrested by the national police and released from prison only after they had signed an excuse letter drafted by Banro.

The company itself emphasises that its compensation and resettlement programmes are in accordance with the 'IFC (International Finance Corporation) Guidelines' on compensation and resettlement and the 'Equator Principles', a minimum due diligence standard for managing social and environmental risk in project financing to which financial institutions voluntarily subscribe (public relations manager 2011 int.). Banro is putting in a lot of money and effort to act as a responsible company, sensitive to social and community issues through the 'Banro Foundation', a charity fund financing health, education, training and leisure programmes. Their communication to the general public and their stockholders is quite efficient. On their informative and attractive website they describe themselves as having 'the passion of a junior and the assets of a major', emphasising the fact that they are the only ones who dare to invest in such a difficult context. They thus base their legitimisation on a set of international guidelines and conventions and a CSR discourse (Banro 2012; see also Geenen \& Hönke, forthcoming).

\section{Shifting power of local elites}

Banro negotiated the compensation and resettlement schemes in the first place with the local authorities, which puts these intermediaries in a very powerful position. Through their close contacts with the company, local elites (including the mwamikazi and members of Codelu) have been able to win some important subcontracting contracts, as well as NGO contracts for training of artisanal miners. In the eyes of part of the population, they are only pursuing their own interests. They would ignore and even counteract the population's interests:

We cannot address Banro directly because we have to pass through these few people who monopolise the contacts. And these are the same people who refrain us! They present themselves as representatives of the 
population, but they are hampering the activities of the common people. Actually the main problem is not Banro itself. The problem lies with these intermediaries who interpret our grievances completely wrongly. (Former miners focus group 2011 int.)

First of all, the customary authorities in Luhwindja managed to manoeuvre themselves into a new and profitable position. They have turned their role as safeguards of the land into that of intermediary between the company and the community. But recently tensions have mounted among Luhwindja's elites. Some groups, including Codelu, accuse the mwamikazi of acting on her own and disregarding the community's interests. The growing disagreement culminated in a petition that circulated in January 2012 and asked for her dismissal. This petition was initiated by some young members of a local human rights organisation and got support from Codelu and political opponents of the mwamikazi (local human rights organisation int.). Among the population they collected more than 4, ooo signatures. Three initiators, however, were charged with forgery and spent six months in prison in Bukavu. In the meantime the situation became highly politicized and the two parties seem far from a consensus. There are even old pretenders to the throne who use this new situation to revive their claims (throne pretender int.).

\section{O N C L U S I O N}

The arrival of Banro added a new layer to the already complex institutional landscape in Luhwindja. It further contributed to the privatisation of the public space and the commodification of natural resources, leading to an increased pressure on the land and a more exclusive access pattern. Local elites often manage to turn this new situation to their benefit. As we have illustrated, state agents, customary chiefs and local leaders try to gain access by forum shopping or 'playing upon' the legal registers at their disposal. If the context is suitable, they control access to land and to the mining rents by using their position as, for example, customary chiefs. If the political economic context changes, they may place themselves as intermediaries between a multinational company and the population. In this sense, we should not only see the discontinuities in eastern DRC's recent history. Many of the access patterns that existed before the war (access control by customary chiefs) continued during and after the war, but it is true that local elites have constantly 'adapted' and shifted along with authority structures at different scales. 
In this local context multinational companies like Banro try to gain access by what Ribot \& Peluso (2003) call 'legal' (contracts with the state) or 'illegal' (violence, contacts with armed groups) mechanisms. In order to maintain their access and secure their concessions they are also bound to establish relationships with local and national authorities and, through selected intermediaries, with the local community (relational mechanisms). They finally use structural mechanisms such as access to technology, capital and markets. Artisanal miners gain and maintain access by referring to 'traditional rights', customary law and seek legitimation in state deficits. They also engage in forum-shopping by negotiating with different authorities over access maintenance. Through relational and structural mechanisms such as access to credit and technology they try to secure their 'ability to benefit'. But as we have illustrated, this is not evident when facing a multinational company in a context of weak state authority. In this complex context of individualisation of access rights, changing power relations and overlapping legal fields, access becomes disputed and, if not managed well, may lead to tense and even violent outcomes.

\section{NOTES}

1. Loi $\mathrm{n}^{\circ} 007 / 2002$ du 11 juillet 2002 portant Code Minier (Mining Law).

2. Décret $\mathrm{n}^{\circ} \mathrm{o} 38 / 2003$ du 26 mars 2003 portant Règlement Minier (Mining Regulations).

3. Mining Law, T. 4, Ch. 1, Art. 1og.

4. Mining Law, T. 4, Ch. 1, Art. 110.

5. Mining Law, T. 4, Ch. 1 , Art. 111 and 112

6. It is estimated that 90 to $95 \%$ of gold from the eastern provinces is smuggled out to neighbouring countries (Garrett \& Mitchell 2009: 32).

7. This section is mainly based on a number of documents, letters and notes from the personal archive of Serge Lammens, former Administrator-General Director of Sominki. See also Kennes (2005) and de Failly (2001).

8. 'Convention minière entre la République du Zaïre et la Société Minière et Industrielle du Kivu 'Sominki' et Banro Resource Corporation', 13.02.1997.

9. The president issued four decrees: Decree n. 101 annulling the Decree that created Sakima, Decree n. 102 annulling the Agreement of 13 February, Decree n. 103 creating Somico and Decree n. 104 nominating Somico's president.

10. Some speculate that his death is related to the Banro-Somico conflict; others refer to elder tensions between two branches of the royal family who both claim the throne.

11. The director of Sakima, Alexis Thambwe, was one of the RCD's founding members. Victor Ngezayo, the director of RMA, was a businessman with Rwandese roots and also supported the rebellion. So the two protagonists on the Banro side were directly involved in the new rebellion.

12. 'Avenant n.1 à la convention minière du 13 février 1997', 18.04.2002.

13. 'Avenant n.2 à la convention minière du 17 février 1997', 13.06 .2010$.

14. A groupement is an administrative unit in the DRC. A province consists of various 'territoires', which consist of 'chefferies' or chiefdom, which consists of 'groupements'. The chief of a groupement is nominated by the chief of the chiefdom, the mwami (see Utshudi Ona \& Ansoms 2011). 


\section{R E F E R E N C E S}

Andrew, J.S. 2003. 'Potential application of mediation to land use conflicts in small-scale mining', Journal of Cleaner Production 1 1: 11 7-30.

Aubynn, A. 2009. 'Sustainable solution or a marriage of inconvenience? The coexistence of largescale mining and artisanal and small-scale mining on the Abosso Goldfields concession in Western Ghana', Resources Policy 34: 64-7o.

Ballard, C. \& G. Banks. 2003. 'Resource wars: the anthropology of mining', Annual Review of Anthropology 32: 287-313.

Banro 2010. 'Barême des taux d'indemnisation et modalités de remplacement des biens immobiliers' (unpublished).

Banro 2012. 'A new direction for the eastern Democratic Republic of the Congo. 2012 Corporate social responsibility report', <www.banro.com>, accessed 1 2.07.2012.

Bebbington, A., L. Hinojosa, D. Humphreys Bebbington, M.L. Burneo \& X. Warnaars. 2008. 'Contention and ambiguity: mining and the possibilities of development', Development and Change $39,6: 887-914$.

Bush, R. 2009. 'Soon there will be no-one left to take the corpses to the morgue. Accumulation and abjection in Ghana's mining communities', Resources Policy 34 : 57-63.

Campbell, B. 20o9. 'Introduction', in B. Campbell, ed. Mining in Africa. Regulation and development. London: Pluto Press, 1-24.

de Failly, D. 2001. 'Coltan: pour comprendre...', in S. Marysse \& F. Reyntjens, eds. L'Afrique des Grands Lacs. Annuaire 20oo-20oI. Paris: L'Harmattan, 279-3o6.

Forum Communautaire Consultatif de Luhwindja/Twangiza Mining SARL (Filiale de Banro Corporation). 2010. 'Résumé des travaux du sous-comité en charge de la question compensation' (unpublished).

Garrett, N. \& H. Mitchell. 20o9. Trading Conflict for Development. Utilising the trade in minerals from eastern DR Congo for development. London: DFID.

Geenen, S. 2011 a. 'Local livelihoods, global interests and the state in the Congolese mining sector', in A. Ansoms \& S. Marysse, eds. Natural Resources and Local Livelihoods in the Great Lakes Region of Africa. A political economy perspective. London: Palgrave Macmillan, 147-69.

Geenen, S. 201 1b. 'Relations and regulations in local gold trade networks in South Kivu, Democratic Republic of Congo', Journal of Eastern African Studies 5, 3: 427-46.

Geenen, S. 2012. 'Who seeks, finds: how artisanal miners and traders benefit from gold in the Eastern Democratic Republic of Congo', European Journal of Development Research. < http://dx.doi. org/doi:10.1057/ejdr.2012.19>.

Geenen, S. \& J. Hönke. Forthcoming. 'Land grabbing by mining companies, local contentions and state reconfiguration in South-Kivu (DRC)', in A. Ansoms \& T. Hilhorst, eds. Everyday Forms of Land Grabbing in the Great Lakes Region.

Griffiths, J. 1986. 'What is legal pluralism?', Journal of Legal Pluralism and Unofficial Law 24: 1-55.

Hilson, G. 2002. 'An overview of land use conflicts in mining communities', Land Use Policy 19: $65-73$.

Hilson, G. \& N. Yakovleva. 2007. 'Strained relations: a critical analysis of the mining conflict in Prestea, Ghana', Political Geography 26: 98-1 19.

Hönke, J. 2010. 'New political topographies. Mining companies and indirect discharge in Southern Katanga (DRC)', Politique Africaine 120 : $105^{-27}$.

Kennes, E. 2005. 'The mining sector in Congo; the victim or the orphan of globalization?', in S. Marysse \& F. Reyntjens, eds. The Political Economy of the Great Lakes Region in Africa. The pitfalls of enforced democracy and globalization. New York: Palgrave Macmillan, $15^{2-89}$.

Marysse, S. 2005. 'Regress, war and fragile recovery: the case of the DR Congo', in S. Marysse \& F. Reyntjens, eds. The Political Economy of the Great Lakes Region in Africa. The pitfalls of enforced democracy and globalization. New York: Palgrave Macmillan, $125^{-} 5^{1}$.

Mazalto, M. 2009. 'Governance, human rights and mining in the Democratic Republic of Congo', in B. Campbell, ed. Mining in Africa. Regulation and development. London: Pluto Press: 187-242.

Meinzen-Dick, R.S. \& R. Pradhan. 2002. Legal Pluralism and Dynamic Property Rights. Washington, DC: CGIAR Systemwide Program on Collective Action and Property Rights, International Food Policy Research Institute.

Ministère des mines RDC. 2007. 'Commission de révisitation des contrats minier. Rapport des travaux' (unpublished). 
Mugangu Matabaro, S. 2008. 'La Crise Foncière à L'Est de la RDC' in S. Marysse, F. Reyntjens \& S. Vandeginste, eds. L'Afrique Des Grands Lacs. Annuaire 2007-2oo8. Paris: L'Harmattan, $3^{8} 5^{-4} 4^{1} 4$.

Observatoire Gouvernance et Paix (OGP). 2008. Potentialités des entités administratives décentralisées: collectivité chefferie de Luhwinja (Sud-Kivu/DR Congo). Bukavu: OGP.

Ribot, J.C. \& N.L. Peluso. 2003. 'A theory of access', Rural Sociology 68, 2: 153-81.

Schlager, E. \& E. Ostrom 1992. 'Property-rights regimes and natural resources: a conceptual analysis', Land Economics 68, 3: 249-62.

Sikor, T. \& C. Lund. 2009. 'Access and property: a question of power and authority', Development and Change 40, 1: 1-22.

Tamanaha, B.Z. 2008. 'Understanding legal pluralism', Sydney Law Review 30: $375^{-41} 1$.

Utshudi Ona, I. \& A. Ansoms. 2011 . 'Reconciling custom, state and local livelihoods: decentralized land management in South Kivu (DRC)', in S. Marysse \& A. Ansoms, eds. Natural Resources and Local Livelihoods in the Great Lakes Region of Africa. London: Palgrave: 26-48.

Van Acker, F. 2005. 'Where did all the land go? Enclosure and social struggle in Kivu (DRCongo)', Review of African Political Economy 32, 103: 79-98.

Vlassenroot, K. 2004. 'Reading the Congolese crisis', in K. Vlassenroot \& T. Raeymaekers, eds. Conflict and Social Transformation in Eastern DR Congo. Gent: Academia Press: 39-6o.

Vlassenroot, K. \& C. Huggins. 2005. 'Land, migration and conflict in eastern DRC', in C. Huggins \& J. Clover, eds. From the Ground Up: Land rights, conflict and peace in Sub-Saharan Africa. Nairobi/ Pretoria: African Centre for Technology Studies/Institute of Security Studies, chapter 4 .

von Benda-Beckmann, K. 1981. 'Forum shopping and shopping forums: dispute processing in a Minangkabau village in West-Sumatra', Journal of Legal Pluralism 19: 117-59.

von Benda-Beckmann, F. \& K. von Benda-Beckmann. 2006. 'The dynamics of change and continuity in plural legal orders', Journal of Legal Pluralism and Unofficial Law 53-54: 1-44.

\section{Interviews}

Businessman, Bukavu, o6.o6.2012

Chef de groupement, Luhwindja, o9.01.2011

Chef de poste, Luhwindja, 24.10.2011

Community leader, Luhwindja, o8.01.2011 and 26.10.2011

Former miner a, Luhwindja, 26.10.2011

Former miner b, Luhwindja, o8.01.2011

Former miners focus group, Luhwindja (Lubanda), o7.01.2011

Former shaft manager a, Luhwindja, 08.01.2011

Former shaft manager b, Luhwindja, 09.01.2011

Lawyer, Bukavu, 3.11.2011

Leader artisanal miners, Luhwindja, o8.01.2011

Local human rights organisation, Bukavu, 28.o9.2012

Local NGO, Bukavu, o8.11.2011

MGL employee, Luhwindja, o8.01.201 1

Miner, Kamituga, 04.04.2008 and 14.04.2008

Miners focus group, Luhwindja (Kaduma), 28.10.2011

Public relations manager (Twangiza Mining), Luhwindja, 10.01.2011

Women focus group, Luhwindja, 28.10.2011

Throne pretender, Bukavu, 10.10.2012 